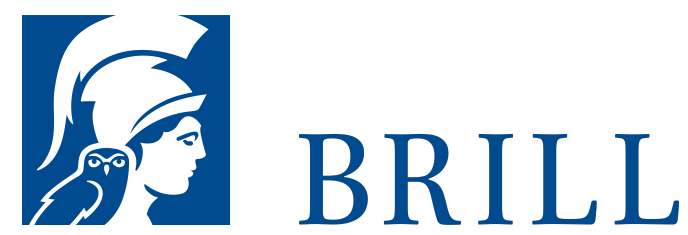

\title{
Handbuch der Wirtschafts- und Sozialgeschichte Deutschlands Bd.1-3/II
}

\section{Author: Friedrich-Wilhelm Henning}

Das Handbuch der Wirtschafts- und Sozialgeschichte Deutschlands von Friedrich-Wilhelm Henning ist zu einem Klassiker der historischen Grundlagenliteratur geworden. Wir bieten dieses immer noch hilfreiche Standardwerk als Komplettpaket zum erschwinglichen Sonderpreis an.

Es ist fraglich, ob jemals wieder ein einzelner Wissenschaftler in der Lage sein wird, so grundlegend, umfassend und souverän die wirtschaftliche und gesellschaftliche Entwicklung Deutschlands vom frühen Mittelalter bis zum Jahr 1945 darzustellen. Der letzte Band des Werkes wurde von Markus Denzel, Professor für Sozial- und Wirtschaftsgeschichte an der Universität Leipzig auf Grundlage weit fortgeschrittener Manuskripte FriedrichWilhelm Hennings ediert.

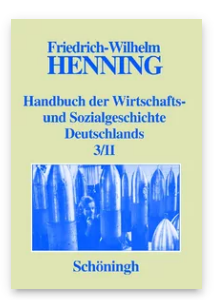

Pages: XXXV + 3992 Seiten

Language:

German

Subjects:

General, History

Publisher: Brill |

Schöningh

Series:

Handbuch der

Wirtschafts- und

Sozialgeschichte

Deutschlands,

Volume: 1-3

Paperback

Publication date: 18 May 2015

ISBN: 978-3506-78262-5 List price

USD \$966.oo 
Friedrich-Wilhelm Henning (1931-2008) war von 1971 bis zu seiner Emeritierung 1996 Direktor des Seminars für Wirtschaftsund Sozialgeschichte der Universität Köln und Wissenschaftlicher Direktor des Rheinisch-Westfälischen Wirtschaftsarchivs in Köln.

For more information see brill.com

Order information: Order online at brill.com +44330333 0049 | customerservices@brill.com Submission information: brill.com/authors

Titles published by Brill | Fink, Brill | mentis or Brill | Schöningh: +49(o)71 5413279216 | brill@brocom.de 